\title{
Animal Reservoirs for Leptospira spp. in South-East Asia: A Meta-Analysis
}

\author{
Aznida Mohamad Zaki', Muhammad Aklil Abd Rahim², Muhammad \\ Haneef Azme ${ }^{3}$, Nor Akila Mahmood ${ }^{4}$, Mohammad Saffree ]effree ${ }^{5}$, \\ Hasanain Faisal Ghazi ${ }^{6}$, Mohd Rohaizat Hassan ${ }^{7}$
}

${ }^{1,3,4,7}$ Department of Community Health, Universiti Kebangsaan Malaysia Medical Centre, 56000 Cheras, Kuala Lumpur, Malaysia ${ }^{2,5}$ Department of Community and Family Medicine, Universiti Malaysia Sabah, Jalan UMS, 88400, Kota Kinabalu, Sabah, Malaysia. ${ }^{6}$ Community Medicine Unit, International Medical School, Management and Science University, University Drive, Off Persiaran Olahraga, 40100 Shah Alam, Selangor, Malaysia.

DOI: https://doi.org/10.24321/2349.7181.201817

\begin{abstract}
Background and Aim: Leptospirosis is a zoonotic disease responsible for high morbidity worldwide. This review is intended to identify other possible animal reservoirs of Leptospira spp. within human surroundings, which may improve the prevention and control of the disease.

Methods: A systematic search was performed for the relevant titles, abstracts and keywords in PubMed, Scopus and Google Scholar in March 2018 based on the PICO strategy; which returned 1226 studies. Screening of abstracts had shortlisted 71 studies and data extraction was conducted for 15 studies which had been accepted after review of the full text. Only studies done in South-East Asia were considered. Meta-analysis of the accepted studies was done to compute the composite prevalence of each animal group using random effects model.

Results: The articles were analysed from the viewpoint of the study settings and the prevalence of Leptospira spp. in types of animal with the animals being grouped into five major groups, based on taxonomy and likelihood of human contact. It was found that all animal groups have statistically significant value of pooled prevalence, with a range between $8.17 \%(95 \% \mathrm{Cl}: 4.80 \%-12.39 \%)$ for sheep and goats, to as high as $27.28 \%$ (95\% Cl: $1.24 \%-69.69 \%)$ for carnivores. The prevalence for other animal groups are $17.95 \%$ (95\% Cl: $7.77 \%$ - 31.18\%) for rodents, $19.24 \%$ (95\% Cl: $10.65 \%-29.65 \%)$ for pigs, and $24.90 \%$ (95\% Cl: $15.45 \%-35.71 \%)$ for ruminants.

Conclusion: Meta-analysis showed that other groups of animals, particularly carnivores, pigs, and large ruminants are just as culpable as rodents in being the reservoir for Leptospira spp. These other groups of animals may also play a vital role in the transmission and overall dynamics of human leptospirosis.

Keywords: Animal reservoirs, Leptospirosis, Prevalence, South-East Asia
\end{abstract}

\section{Introduction}

Leptospirosis is a zoonotic disease with high morbidity in tropical countries with incidence ranging from 10 to 100 cases per 100,000 individuals. ${ }^{1}$ It is caused by a spirochete bacterium in the genus Leptospira spp. and transmitted to humans through animal urine or contaminated soil or water. In 2015, it was estimated that there were 1.03

Corresponding Author: Muhammad Aklil Abd Rahim, Department of Community and Family Medicine, Universiti Malaysia Sabah, Jalan UMS, 88400, Kota Kinabalu, Sabah, Malaysia.

E-mail Id: aklil@ums.edu.my

Orcid Id: https://orcid.org/0000-0002-1087-4444

How to cite this article: Zaki AM, Rahim MAA, Azme MH et al. Animal Reservoirs for Leptospira spp. in South-East Asia: A MetaAnalysis. J Adv Res Med 2018; 5(3): 23-31. 
million cases (95\% Cl:434,000-1,750,000) annually with 58,900 deaths $(95 \% \mathrm{Cl}: 23,800-95,900)$ globally. ${ }^{2}$ Almost half of the cases (48\%; $95 \% \mathrm{Cl}: 40-61 \%$ ) and more than two fifths of deaths (42\%; $95 \% \mathrm{Cl} 34-53 \%)$ were estimated to occur in adult males with the age of 20-49 years. ${ }^{2}$ The highest estimates of disease morbidity and mortality were observed in South Asia, Southeast Asia, Tropical Latin America, Central America, Oceania, East Sub-Saharan Africa, and Caribbean and Andean regions. ${ }^{2}$

The epidemiology of leptospirosis has been extensively studied in urban communities, where rats are thought to be the main vector of human leptospirosis in urban settings. ${ }^{3,4}$ For high risk occupational exposure, cattle and pigs are thought to be the animal reservoir for the disease. ${ }^{5}$ Further, an increasing number of studies revealed that other animals can also be the reservoir. ${ }^{6,7}$ Hence, this review is intended to identify the possible animal reservoir of Leptospira spp. within human surroundings. Understanding the source and animal reservoir of leptospirosis may provide insights into the transmission process that can ultimately be utilised to prevent and control this disease. The objectives of this systematic review are to identify animal reservoirs for leptospirosis, determine the prevalence of Leptospira spp. in animal reservoirs and identify high-risk animal reservoirs for human leptospirosis.

\section{Methods}

\section{Search Method}

Systematic search was performed for the relevant titles, abstracts and keywords in the journal databases of PubMed, Google Scholar and Scopus on March 2018 based on the PICO strategy (Figure 1). A total of 1226 studies were retrieved; keywords and terms entered were (leptospirosis OR leptospira OR zoonotic OR "Weil's Disease" Or "field fever" OR "rat catcher's yellows" OR "pretibial fever" OR Asia) AND ("animal reservoir" OR rat OR rodent* OR mouse OR mice OR pig* OR cattle OR livestock* OR pet OR dog* OR cat) AND (prevalence OR incidence) without restrictions on the publication date. Only original research, published articles and articles written in the English language were selected. Screening of abstracts had shortlisted 71 studies and data extraction was conducted. However, only 15 studies had been accepted after review of the full texts. The other 56 articles were excluded due to them being: (1) conducted outside of the South-East Asia region; (2) involving wild animals; (3) utilising methods of seropositivity detection other than the Microagglutination Test (MAT); and (4) having a small sample size of less than 30 individual animals.

\section{Data Analysis}

The studies included for meta-analysis are in principal homogenous in terms of the methodology, the method of Leptospira spp. detection, and the setting. Heterogeneity may still be present and is likely due to systematic bias and is tested by chi squared with $p<0.01$ denoting level of significance. The quantification of the degree of heterogeneity was done using the $\mathrm{I}^{2}$ statistic, which represents the percentage of the total variability across studies. To quantify the degree of heterogeneity, ${ }^{2}$ value of more than $75 \%$ is considered as highly heterogenous but is still included in the meta-analysis, as it is assumed that the studies included were answering similar research questions. Studies were assessed for systematic bias by scrutinizing the funnel plot. A study that falls outside of the funnel is considered as having high bias and may not be included in the meta-analysis. For each group of animals, at least 5 studies were included for the calculation of the prevalence. Analyses were performed using MedCalc Statistical Software version 18.2.1. ${ }^{8}$ Random effects model was used to calculate the prevalence of Leptospira spp. in each group of animals.

\section{Results}

\section{Settings}

A total of 15 articles exploring the prevalence of Leptospira spp. among animals from various settings in South-East Asia were analyzed (Table 1). The prevalence ranges were between $0.6 \%$ to $92.45 \%$, being dependent on the MAT cut-off point used. Common animals studied in these articles were rodents, pigs, cattle, buffaloes, sheep, goat and carnivores such as cats, dogs, and civets. The studies were conducted in 15 South-East Asian countries, whereby $5(33.33 \%)$ were in Thailand, followed by Malaysia (4; $26.67 \%)$, Vietnam (3; 20.00\%), Philippines (2; $13.33 \%)$, and Indonesia ( $1 ; 6.67 \%)$. Animal samples were either obtained from livestock or captured strays. The majority of studies obtained samples from livestock or animal farms (9; $60.00 \%)$, while $3(20.00 \%)$ were obtained from captured rodents around the residential area or from stray animals. Others include abattoirs $(2 ; 13.33 \%)$ and one $(6.67 \%)$ each from animals captured in the forest or shrubs, places of worship, veterinary clinic and a National Service camp.

\section{Types of Animal}

Ten studies researched a single animal whereas the remaining looked into leptospirosis in multiple animals. The most studied animal was pigs ( $8 ; 53.33 \%)$. Four of these studies were focused on pigs alone whereas the other four studies also included other farm animals such as cattle, buffalo, sheep and goat. A total of 9219 samples from pigs were taken in the studies. Rodents and buffaloes were the second most studied animal (5; 33.33\%) with 2185 and 2441 samples respectively. Cattles were studied in four $(26.67 \%)$ researches with 4314 samples. Three 
studies (20\%) looked into dogs, two studies (13.33\%) had sheep while cats were researched in one study (6.67\%). One study also included other animals such as squirrel, reptiles, shrews, birds, ox and other mammals. ${ }^{9}$

\section{Microscopic Agglutination Test}

MAT cut-off titres differed in the 15 included studies. The cut-off titres used were as low as 1:20, up to 1:400. Three studies conducted in Vietnam, Thailand and the Philippines used MAT cut-off titre of 1:20 to determine the seroprevalence in rats and dogs. One study conducted in Thailand among livestock used a cut-off titre of 1:50. Majority of the studies used cut-off titres of 1:100 and only two studies used cut-off titres of 1:400. In those 15 studies, different sets of reference antisera were used to identify different serovars depending on the local endemicity. The different number of antigens panel used ranges from 10 to 39 antisera. The most common panel used is by WHO/ FAO/OIE which can be tested against 23 serovars.

\section{Prevalence}

It was found that there were a total of 13 groups of different animals; they are then placed into larger groups (total of 5 groups) based on similar taxonomy and likelihood of contact with humans. Leptospira spp. prevalence in pigs ranged from $8.2 \%$ to $73.4 \%$, while rats/rodents' prevalence was from as low as $6.7 \%$ up to $92.5 \%$. Large ruminants (buffaloes, cattle, ox) had a prevalence range from $3.8 \%$ to $40.5 \%$, while the prevalence in small ruminats like sheep and goats were between $4.4 \%$ and $27.9 \%$. Carnivores (dogs, cats, civets) on the other hand had $8.8 \%$ to $89.1 \%$ prevalence. There were few studies on other animals including reptiles (14.0\%), squirrels $(5.0 \%)$, shrews $(0.8 \%)$, bats $(0.7 \%)$ and birds (0.6\%).

Table 1.Summary of studies included in the analysis

\begin{tabular}{|c|c|c|c|c|c|c|c|}
\hline & $\begin{array}{l}\text { Author } \\
\text { and year }\end{array}$ & Study design \& settings & $\begin{array}{l}\text { Method of } \\
\text { detecting } \\
\text { Leptospira } \\
\text { spp. }\end{array}$ & Type of animal & $\begin{array}{l}\text { No. of } \\
\text { sample }\end{array}$ & $\begin{array}{l}\text { No. of } \\
\text { positive } \\
\text { samples }\end{array}$ & $\begin{array}{l}\text { Prevalence } \\
\text { of } \\
\text { Leptospira }\end{array}$ \\
\hline 1. & Lee et al. ${ }^{10}$ & $\begin{array}{l}\text { Cross-sectional. } \\
\text { Slaughterhouses } \\
\text { from } 5 \text { provinces } \\
\text { Vietnam } \\
\end{array}$ & MAT $\geq 1: 100$ & Pigs & 1959 & 160 & $8.17 \%$ \\
\hline 2. & $\begin{array}{l}\text { Chadsuthi et } \\
\text { al. }{ }^{11}\end{array}$ & $\begin{array}{l}\text { Cross-sectional. } \\
\text { Thailand. } \\
\text { National passive } \\
\text { surveillance data on } \\
\text { leptospirosis infection } \\
\text { in livestock. }\end{array}$ & MAT $\geq 1: 100$ & \begin{tabular}{|l} 
Buffaloes \\
Cattle \\
Pigs
\end{tabular} & $\begin{array}{l}432 \\
3648 \\
3138\end{array}$ & $\begin{array}{l}107 \\
1026 \\
356\end{array}$ & $\begin{array}{l}24.8 \% \\
28.1 \% \\
11.3 \%\end{array}$ \\
\hline 3. & Loan et al. ${ }^{12}$ & $\begin{array}{l}\text { Cross-sectional. } \\
\text { Farms in } 12 \text { Mekong } \\
\text { Delta provinces, } \\
\text { Vietnam }\end{array}$ & MAT $\geq 1: 20$ & Rat & 241 & 44 & $18.26 \%$ \\
\hline 4. & $\begin{array}{l}\text { Suwanc- } \\
\text { haroen et } \\
\text { al. }{ }^{13}\end{array}$ & $\begin{array}{l}\text { Cross-sectional. } \\
\text { Livstock, } 36 \text { provinces } \\
\text { in } \\
\text { Thailand. }\end{array}$ & MAT $\geq 1: 50$ & $\begin{array}{l}\text { Cattle } \\
\text { Buffalo } \\
\text { Pig } \\
\text { Sheep } \\
\text { Goat }\end{array}$ & $\begin{array}{l}9288 \\
1376 \\
1898 \\
1110 \\
516\end{array}$ & $\begin{array}{l}918 \\
419 \\
205 \\
52 \\
41\end{array}$ & $\begin{array}{l}9.88 \% \\
30.45 \% \\
10.80 \% \\
4.68 \% \\
7.95 \%\end{array}$ \\
\hline 5. & $\begin{array}{l}\text { Niwetpa- } \\
\text { thomwat et } \\
\text { al. }{ }^{14}\end{array}$ & $\begin{array}{l}\text { Cross-sectional. } \\
10 \text { sow farms in } 4 \\
\text { provinces in } \\
\text { central Thailand }\end{array}$ & MAT $\geq 1: 100$ & Pigs & 400 & 40 & $10 \%$ \\
\hline 6. & $\begin{array}{l}\text { Meeyam et } \\
\text { al. }^{15}\end{array}$ & $\begin{array}{l}\text { Out-patient } \\
\text { department of the } \\
\text { small animal hospital, } \\
\text { faculty } \\
\text { of Veterinary Medicine, } \\
\text { Chiang Mai University, } \\
\text { Thailand }\end{array}$ & MAT $\geq 1: 20$ & Dogs & 210 & 23 & $11 \%$ \\
\hline
\end{tabular}




\begin{tabular}{|c|c|c|c|c|c|c|c|}
\hline 7. & $\begin{array}{l}\text { Bahaman et } \\
\text { al. }{ }^{16}\end{array}$ & $\begin{array}{l}\text { Cross-sectional. } \\
\text { Blood samples from } \\
\text { animals in government } \\
\text { farms, small holdings } \\
\& \text { animals sent for } \\
\text { slaughter in abattoir in } \\
\text { West Malaysia }\end{array}$ & MAT $\geq 1: 40$ & $\begin{array}{l}\text { Total } \\
\text { Cattle } \\
\text { Water buffaloes } \\
\text { Goats } \\
\text { Pigs } \\
\text { Sheep }\end{array}$ & $\begin{array}{l}3377 \\
1378 \\
429 \\
657 \\
869 \\
44\end{array}$ & $\begin{array}{l}862 \\
558 \\
133 \\
29 \\
139 \\
3\end{array}$ & $\begin{array}{l}25.5 \% \\
40.5 \% \\
31 \% \\
4.4 \% \\
16 \% \\
6.8 \%\end{array}$ \\
\hline 8. & Smith et al. ${ }^{9}$ & $\begin{array}{l}\text { Cross-sectional. } \\
\text { Animal species were } \\
\text { trapped in forest } \\
\text { localities, rice field } \\
\text { areas, areas of scrub } \\
\text { and cultivation and in } \\
\text { several } \\
\text { towns and villages, } \\
\text { Malaysia }\end{array}$ & MAT $\geq 1: 100$ & $\begin{array}{l}\text { House rats and mice } \\
\text { Rats of scrub and } \\
\text { cultivation } \\
\text { Forest ground rats } \\
\text { Forest tree rats } \\
\text { Tree shrews } \\
\text { Squirrels } \\
\text { Shrew } \\
\text { Carnivore } \\
\text { Bats } \\
\text { Other mammals } \\
\text { Birds } \\
\text { Reptiles } \\
\text { Ox } \\
\text { Goat } \\
\text { Buffalo } \\
\text { Pig } \\
\text { Dog } \\
\text { Cat }\end{array}$ & $\begin{array}{l}393 \\
701 \\
\\
522 \\
147 \\
101 \\
237 \\
44 \\
57 \\
295 \\
25 \\
173 \\
116 \\
52 \\
61 \\
34 \\
47 \\
51 \\
68\end{array}$ & $\begin{array}{l}26 \\
42 \\
50 \\
1 \\
3 \\
1 \\
2 \\
9 \\
4 \\
5 \\
1 \\
16 \\
2 \\
17 \\
5 \\
5 \\
9 \\
6\end{array}$ & $\begin{array}{l}6.6 \% \\
6 \% \\
9.6 \% \\
1 \% \\
3 \% \\
0.8 \% \\
5 \% \\
8.8 \% \\
0.7 \% \\
20 \% \\
0.6 \% \\
14 \% \\
3.8 \% \\
27.9 \% \\
14.7 \% \\
10.6 \% \\
17.6 \% \\
8.8 \%\end{array}$ \\
\hline 9. & $\begin{array}{l}\text { Villanueva et } \\
\text { al. }{ }^{17}\end{array}$ & $\begin{array}{l}\text { Cross-sectional. } \\
\text { Intensive-type farm in } \\
\text { the Philippines }\end{array}$ & MAT $\geq 1: 40$ & $\begin{array}{l}\text { Rat } \\
\text { Water buffalo }\end{array}$ & $\begin{array}{l}10 \\
170\end{array}$ & $\begin{array}{l}3 \\
81\end{array}$ & $\begin{array}{l}30 \% \\
48 \%\end{array}$ \\
\hline 10. & $\begin{array}{l}\text { Villanueva et } \\
\text { al. }{ }^{18}\end{array}$ & $\begin{array}{l}\text { Cross-sectional. } \\
\text { Metro Manila, } \\
\text { the Philippines }\end{array}$ & MAT $\geq 1: 20$ & Rat & 106 & 98 & $92.45 \%$ \\
\hline 11. & $\begin{array}{l}\text { Mohamed- } \\
\text { Hassan et } \\
\text { al. }{ }^{19}\end{array}$ & $\begin{array}{l}\text { Cross-sectional. } \\
\text { National Service } \\
\text { Training Centres } \\
\text { in Kelantan and } \\
\text { Terengganu, Malaysia } \\
\end{array}$ & $\begin{array}{l}\text { MAT } \geq 1: 20 \\
\text { MAT } \geq 1: 40\end{array}$ & Rat & $\begin{array}{l}168 \\
168\end{array}$ & $\begin{array}{l}30 \\
14\end{array}$ & $\begin{array}{l}17.9 \% \\
8.3 \%\end{array}$ \\
\hline 12. & $\begin{array}{l}\text { Al-Khleif et } \\
\text { al. }^{20}\end{array}$ & $\begin{array}{l}\text { Cross-sectional. } \\
\text { Farms in provinces of } \\
\text { Bali, Indonesia }\end{array}$ & MAT $\geq 1: 100$ & Pig & 484 & 131 & $27.07 \%$ \\
\hline 13. & $\begin{array}{l}\text { Jittapa- } \\
\text { lapong et } \\
\text { al. }{ }^{21}\end{array}$ & $\begin{array}{l}\text { Cross-sectional. } \\
\text { Around Buddhist } \\
\text { monasteries in a } \\
\text { district } \\
\text { located in the center of } \\
\text { Bangkok, Thailand }\end{array}$ & MAT $\geq 1: 100$ & Dog & 230 & 205 & $89.13 \%$ \\
\hline 14. & $\begin{array}{l}\text { Boqvist et } \\
\text { al. }{ }^{22}\end{array}$ & $\begin{array}{l}\text { Cross-sectional. } \\
\text { Pig farms in the } \\
\text { Mekong delta, Vietnam }\end{array}$ & $\begin{array}{l}\text { MAT } \geq 1: 100 \\
\text { MAT } \geq 1: 400\end{array}$ & Pig & $\begin{array}{l}424 \\
424\end{array}$ & $\begin{array}{l}311 \\
124\end{array}$ & $\begin{array}{l}73.35 \% \\
29.25 \%\end{array}$ \\
\hline 15. & $\begin{array}{l}\text { Benacer et } \\
\text { al. }^{23}\end{array}$ & $\begin{array}{l}\text { Cross-sectional. } \\
\text { Urban rats from } 3 \mathrm{KL} \\
\text { sites, Malaysia }\end{array}$ & MAT $\geq 1: 400$ & Rat & 300 & 20 & $6.7 \%$ \\
\hline
\end{tabular}




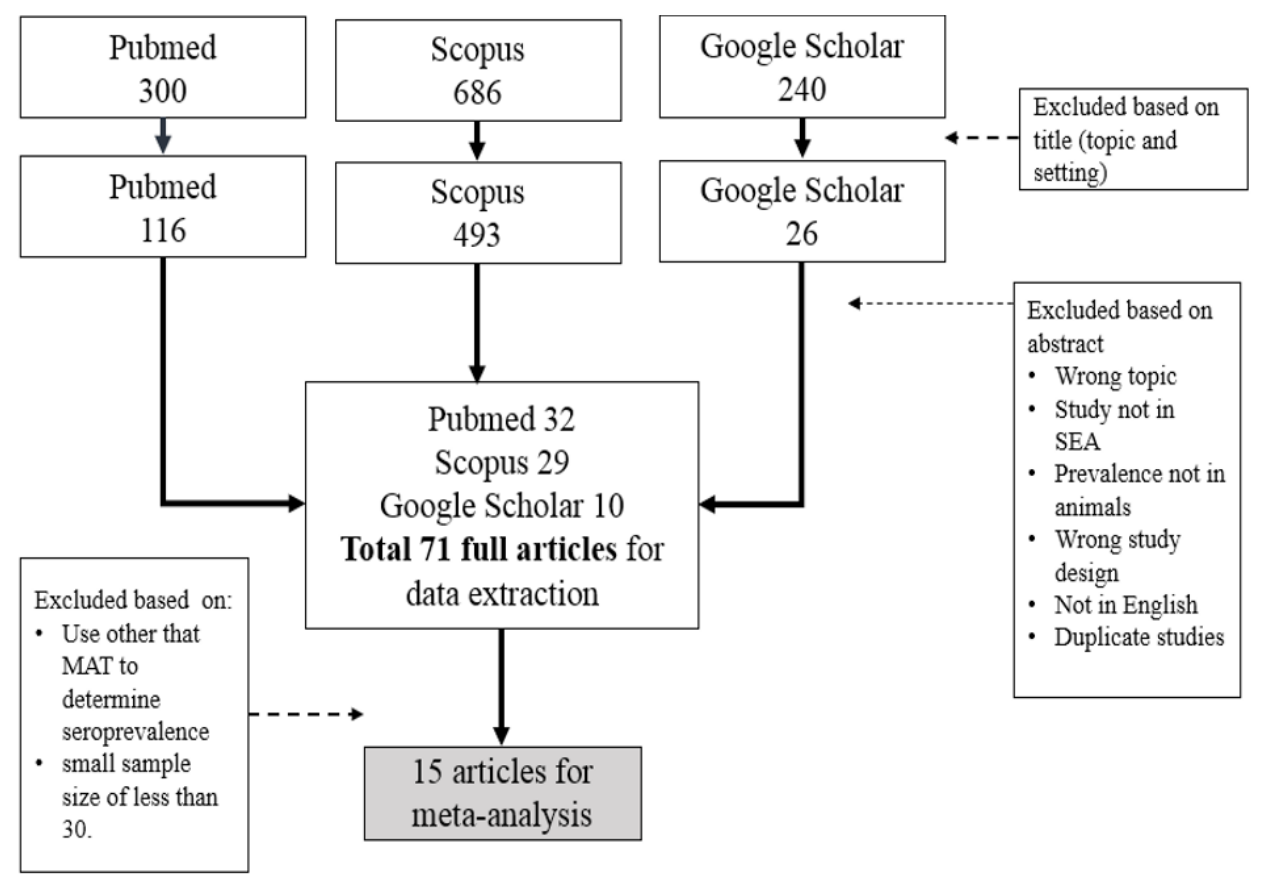

Figure 1.Search method

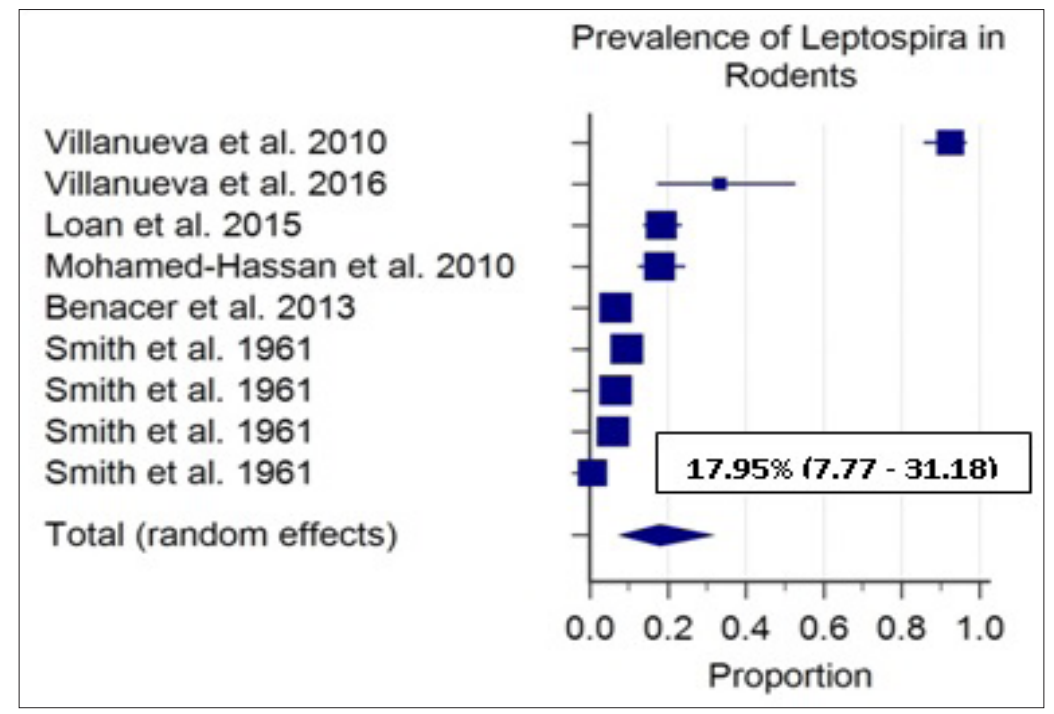

Figure 2.Prevalence of Leptospira in rodents

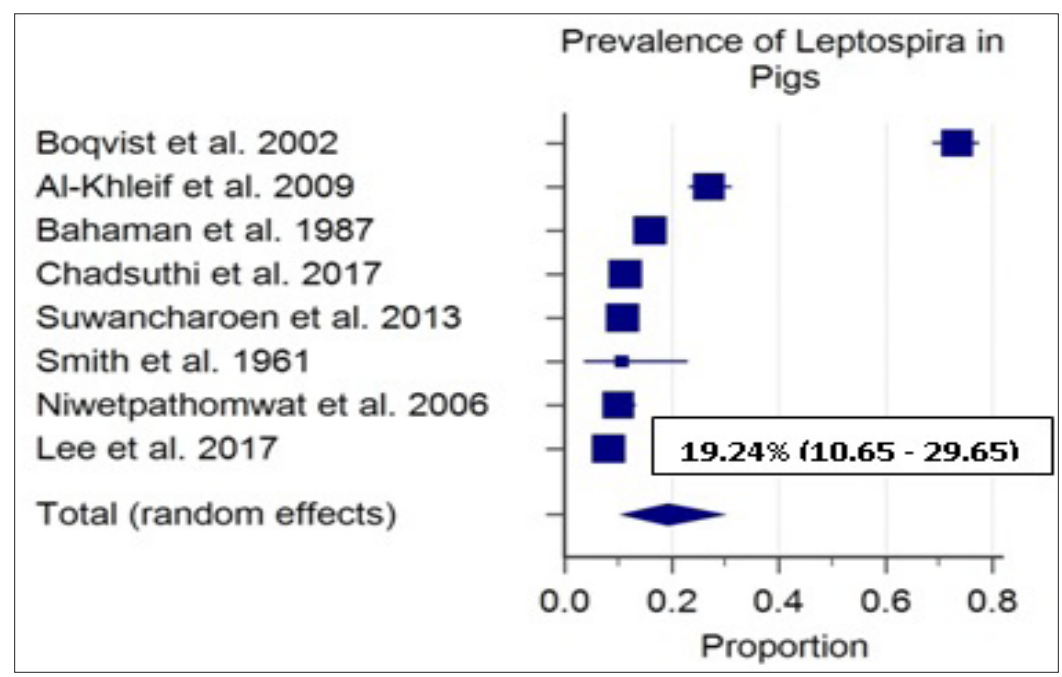

Figure 3.Prevalence of Leptospira in pigs 


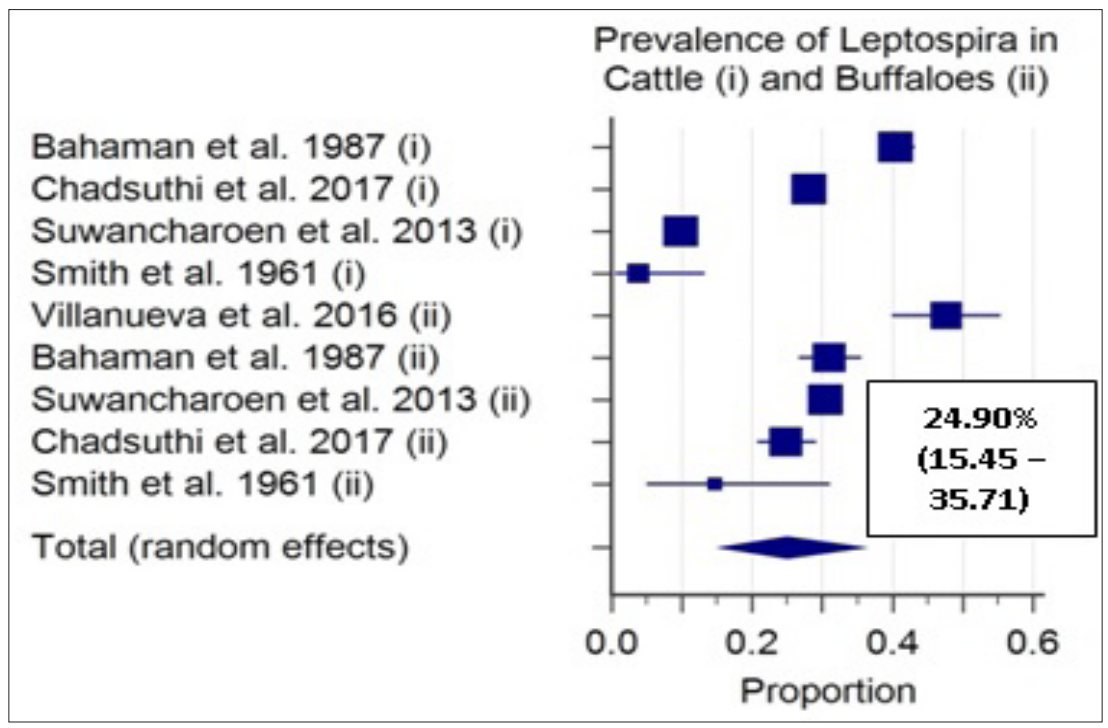

Figure 4.Prevalence of Leptospira in cattle and buffaloes

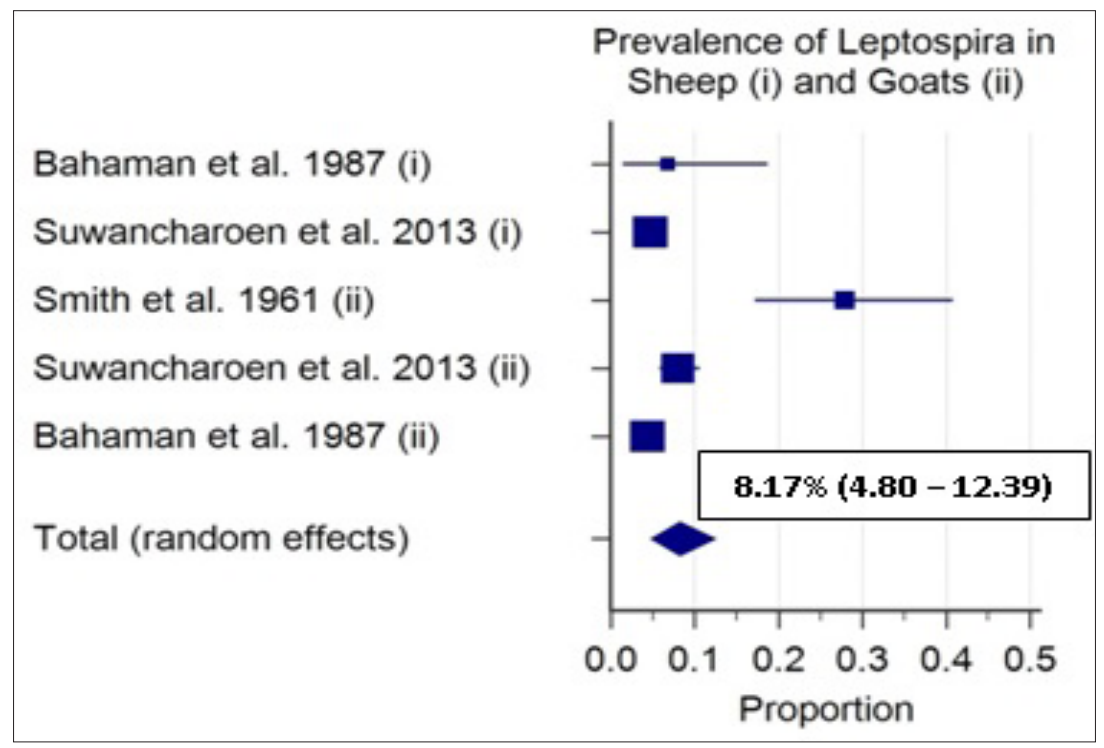

Figure 5.Prevalence of Leptospira in sheep and goats

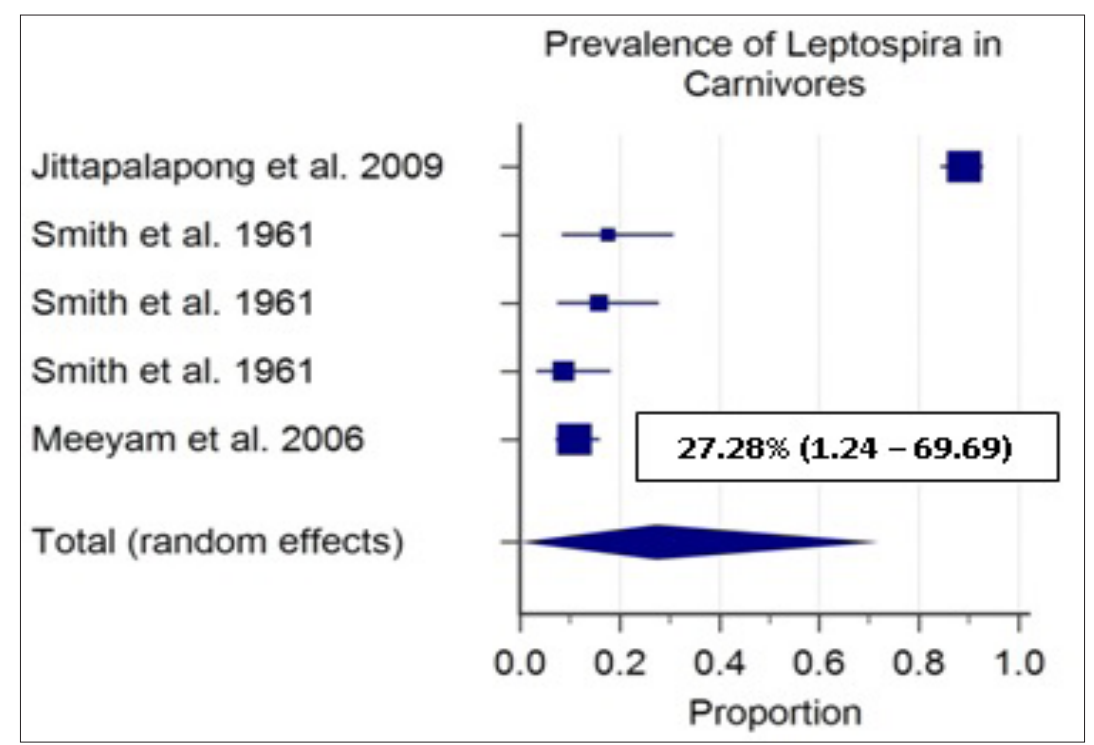

Figure 6.Prevalence of Leptospira in carnivores 


\section{Meta-Analysis}

Meta-analysis was done to determine the pooled prevalence of Leptospiral infection. Animals were grouped according to taxonomy or likelihood of human contact. Rodents were considered together as one group and includes all species of rats and mice. Domestic pigs meant for human consumption made up the second group, while the third group consisted of ruminants like cattle and buffaloes. Next, sheep and goats formed another group, while cats, dogs and other carnivores such as civet were considered together in a group (denoted as carnivores) since these species share similarities in terms of contact with humans (as pets or as stray animals) and taxonomy.

The prevalence of Leptospira in rodents serves as a control for the comparison with other reservoir animals. Six studies on rodents were identified, including one study which had four different species of rodents analysed, and were considered separately in this analysis. ${ }^{9}, 12,17-19,23$ Range of prevalence were from as high as $92.45 \%{ }^{18}$ to as low as $0.68 \% .{ }^{9}$ Tests of heterogeneity showed that Chi-squared was $484.15(p<0.01)$, with high heterogeneity $\left(I^{2}=98.35 \%\right)$. Random effects model showed prevalence was $17.95 \%$ (95\% $\mathrm{Cl}: 7.77 \%-31.18 \%$ ) (Figure 2). The next group of animals

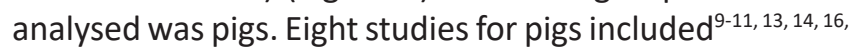
${ }^{20,22}$ with range of prevalence were from as high as $73.35 \%^{22}$ to as low as $8.17 \% .{ }^{10}$ Tests of heterogeneity showed that Chi-squared was 871.55 ( $p<0.01$ ), with high heterogeneity $\left(I^{2}=99.20 \%\right)$. Via random effects model, the prevalence was 19.24\% (95\% Cl:10.65\%-29.65\%) (Figure 3). In Figure 4, there were four studies concerning cattle labelled as (i $)^{9,}$ $11,13,16$ and five studies for buffaloes, labelled as (ii). $9,11,13$, 16, 17 Range of prevalence were from as high as $47.65 \%{ }^{17}$ to as low as $3.85 \%{ }^{9}$. Tests of heterogeneity showed that Chi-squared was 1334.86 ( $p<0.01)$, with high heterogeneity $\left(I^{2}=99.40 \%\right)$. Via random effects model, the prevalence was 24.90\% (95\% Cl:15.45\%-35.71\%).

There were two studies concerning sheep denoted with (i) ${ }^{13,16}$ and three studies for goats labelled as (ii) (Figure 5)..$^{9,13,16}$ Range of prevalence were from as high as $27.87 \%$ ${ }^{9}$ to as low as $4.41 \% .{ }^{16}$ Tests of heterogeneity showed that Chi-squared was 34.10 ( $p<0.01)$, with high heterogeneity $\left(\mathrm{I}^{2}=88.27 \%\right)$. Via random effects model, the prevalence was noted to be $8.17 \%$ (95\% Cl:4.80\%-12.39\%). For carnivores, which consisted of cats, dogs and civets, they were analysed together in a Forest plot (Figure 6). Three studies were identified which had carnivores in its sampling; including one study which had three different types of carnivores analysed, and were considered separately in this analysis. ${ }^{9,}$ 15,21 Range of prevalence in carnivores were from as high as $89.13 \%{ }^{21}$ to as low as $8.82 \% .^{9}$ Tests of heterogeneity showed that Chi-squared was $444.42(p<0.01)$, with high heterogeneity $\left(I^{2}=99.10 \%\right)$. Via random effects model, the prevalence was $27.28 \%$ (95\% Cl:1.24\%-69.69\%).

\section{Discussion}

In most studies, the animals were sampled from livestock or animal farms. The risk of contracting leptospirosis for these animals is different compared to wild animals. Livestock animals live in a controlled environment with clean surroundings, as compared to the wilds. These animals are also well-fed and do not have to fend for themselves from the weather elements and predators; unlike the wilds or stray animals. Thus, livestock animals had less risk to be exposed to Leptospiral infection and became a reservoir. Pets are also considered as animals with low risk of Leptospiral exposure; even lower than that of livestock. Meeyam et al. had taken sera samples from dogs brought to out-patient department of animal hospital in Chiang Mai, Thailand, and found that presence of Leptospira antibodies was only $10.95 \% .{ }^{15}$ On the contrary, another study conducted among stray dogs around Buddhist monasteries in the centre of Bangkok found, found that the presence of Leptospira antibodies was $89.13 \% .{ }^{21}$ The specific settings in which the studies were conducted in play a pivotal role in determining the prevalence of Leptospira in animals studied, and thus a degree of heterogeneity is expected.

Most studied animals were domestic mammals and rodents as these animals have been established as reservoir hosts for leptospirosis. This finding is similar to study done in Pacific Islands which found that cattle, pigs, dogs and rodents may play significant roles in disease transmission to humans. ${ }^{24}$ Although other animals can also carry Leptospira, domestic mammals and rodents carry the highest risk of infecting humans as they are in close contact with humans. ${ }^{25}$ Farm animals like pigs, cows and cattle are managed by human workers from birth to slaughter, and dogs and cats are among the most favoured pets among humans. Additionally, rodent infestations are common in sewers and public places.

Microscopic agglutination test (MAT) is the World Health Organisation (WHO) gold standard test used to diagnose leptospirosis. ${ }^{26}$ MAT detects both IgM and IgG, but cannot differentiate between current, recent, or past infections. It uses a specific panel of antigens for each test depending on the region of sample collection, availability of antigens and cost-effectiveness. An incomplete panel may be responsible for causing false negative results. In areas where endemic strains are unknown or poorly characterised, low seroprevalence may be due to a lack of utilising the correct panel of antigens. ${ }^{27}$ Different cut-off points or titres used in those mentioned studies may affect the seroprevalence in animals. There is no established cut-off point on MAT titre for some of animals. The 1: 100 titre recommended by the World Organization for Animal Health (OIE) is considered positive for international trade, but lower MAT titres may indicate previous exposure to Leptospira. ${ }^{28}$ The decision 
to set a low cut-off point at 1:20 may be due to the fact that serum antibody levels often decline to undetectable levels in chronic leptospirosis infections such as in rat and cattle. Leptospires within the proximal renal tubules, genital tract and mammary glands of animal have been shown to be protected from circulating antibodies which allows persistence and multiplication in these areas. ${ }^{29} \mathrm{~A}$ low titre is appropriate in a population in which exposure to leptospirosis is uncommon, but if exposure is frequent, as in most tropical countries, a higher cut-off titre is necessary. ${ }^{30}$

There are variability and wide ranges in prevalence of Leptospira spp. within each group of animals. This could be affected by the grouping of animals in the analysis. Some studies broadly categorized different species of similar types of animals as one distinct group; e.g. Rattus rattus (black rat), Rattus norvegicus (brown rat) and Mus musculus (house mice) are all considered as "rats" without any differentiation. Moreover, different species/sub-species of the same group of animals harbour different and distinct serovars of leptospires. As an example, different rodent species may be reservoirs of distinct serovars, with rats generally being hosts for serovars of the serogroups Icterohaemorhagiae and Ballum, and house mice are usually hosts for serogroup Ballum. Domestic animals are also potential distinct hosts; with dairy cattle usually harboring the serovars hardjo, pomona, and grippotyphosa; pigs could be hosting pomona, tarassovi, or bratislava; sheep usually are hosts for hardjo and pomona; and dogs may harbor canicola serovar. ${ }^{31}$ These different types of serovar which are distinct and unique to each animal might influence the sensitivity and specificity of the MAT test in detecting Leptospira.

Different geo-location and weather in each study setting might change the level of Leptospiral endemicity, thus requiring different MAT titre values used as cut-off points for Leptospiral detection at each setting to reflect the varying endemicity. Prevalence of leptospirosis is considerably higher in warm-climate countries than in temperate ones; due to longer survival of leptospires in warmer, more humid environment. Many tropical countries are agricultural countries. Therefore, there are greater risk for exposure of the human population to infected animals, either livestock, domestic pets, or wild/feral animals. The disease is markedly seasonal, with peak incidence occurring during summer or fall in temperate regions, where temperature is the limiting factor in the survival of leptospires, and during rainy seasons in warm-climate regions, where rapid desiccation would otherwise prevent survival. ${ }^{32}$ Different level of expertise among the researchers/lab technicians from all research groups and difference in the reliability of the laboratory machines/apparatus being used in the studies to analyse data could also influenced the final reported prevalence, which is also a reflection of the availability of laboratory diagnosis and facility. ${ }^{32}$

\section{Conclusion}

Apart from rodents which are traditionally known for Leptospiral transmission, other groups of animals, particularly carnivores, pigs and large ruminants are also identified as the high-risk animal reservoirs. Thus, rodent control alone is insufficient and focus should also be given to these other groups of animals in preventing human leptospirosis.

\section{Conflict of Interest: None}

\section{References}

1. Guerra MA. Leptospirosis: public health perspectives. Biologicals : journal of the International Association of Biological Standardization 2013; 41(5):295-7.

2. Costa F, Hagan JE, Calcagno J et al. Global Morbidity and Mortality of Leptospirosis: A Systematic Review. PLoS Neglected Tropical Diseases 2015; 9(9): e0003898.

3. Felzemburgh RDM, Ribeiro GS, Costa F et al. Prospective Study of Leptospirosis Transmission in an Urban Slum Community: Role of Poor Environment in Repeated Exposures to the Leptospira Agent. PLoS Neglected Tropical Diseases 2014; 8(5): e2927.

4. Ribeiro P, Bhatt N, Ali S et al. Seroepidemiology of leptospirosis among febrile patients in a rapidly growing suburban slum and a flood-vulnerable rural district in Mozambique, 2012-2014: Implications for the management of fever. International journal of infectious diseases 2017; 64: 50-7.

5. Denipitiya DTH, Chandrasekharan NV, Abeyewickreme $W$ et al. Identification of cattle, buffaloes and rodents as reservoir animals of Leptospira in the District of Gampaha, Sri Lanka. BMC research notes 2017; 10(1): 134.

6. Dietrich $M$, Mühldorfer K, Tortosa P et al. Leptospira and Bats: Story of an Emerging Friendship. PLOS Pathogens 2015; 11(11): e1005176.

7. Schuller S, Francey T, Hartmann K et al. European consensus statement on leptospirosis in dogs and cats. The Journal of small animal practice 2015; 56(3): 159-79.

8. MedCalc Statistical Software version 18.2.1 (MedCalc Software bvba O, Belgium; http://www.medcalc.org; 2018).

9. Smith G, Turner L, Harrison J et al. Animal leptospirosis in Malaya. WHO chronicle 1961; 15: 343-5.

10. Lee HS, Khong NV, Xuan HN et al. Sero-prevalence of specific Leptospira serovars in fattening pigs from 5 provinces in Vietnam. BMC veterinary research 2017; 
13(1): 125.

11. Chadsuthi S, Bicout DJ, Wiratsudakul A et al. Investigation on predominant Leptospira serovars and its distribution in humans and livestock in Thailand, 2010-2015. PLoS Neglected Tropical Diseases 2017; 11(2): e0005228.

12. Loan HK, Van Cuong N, Takhampunya R et al. How important are rats as vectors of leptospirosis in the Mekong Delta of Vietnam?. Vector Borne and Zoonotic Diseases 2015; 15(1): 56-64.

13. Suwancharoen $D$, Chaisakdanugull $Y$, Thanapongtharm $W$ et al. Serological survey of leptospirosis in livestock in Thailand. Epidemiology and infection 2013; 141 (11): 2269-77.

14. Niwetpathomwat A, Luengyosluechakul S, Geawduanglek S. A serological investigation of leptospirosis in sows from central Thailand. The Southeast Asian journal of tropical medicine and public health 2006; 37(4): 716-9.

15. Meeyam T, Tablerk P, Petchanok B et al. Seroprevalence and risk factors associated with leptospirosis in dogs. The Southeast Asian journal of tropical medicine and public health 2006; 37(1): 148-53.

16. Bahaman AR, Ibrahim AL, Adam H. Serological prevalence of leptospiral infection in domestic animals in West Malaysia. Epidemiology and infection 1987; 99(2): 379-92.

17. Villanueva MA, Mingala CN, Gloriani NG et al. Serological investigation of Leptospira infection and its circulation in one intensive-type water buffalo farm in the Philippines. The Japanese journal of veterinary research 2016; 64(1): 15-24.

18. Villanueva SY, Ezoe H, Baterna RA et al. Serologic and molecular studies of Leptospira and leptospirosis among rats in the Philippines. The American journal of tropical medicine and hygiene 2010; 82(5): 889-98.

19. Mohamed-Hassan SN, Bahaman AR, Mutalib AR et al. Serological prevalence of leptospiral infection in wild rats at the National Service Training Centres in Kelantan and Terengganu. Tropical biomedicine 2010; 27(1): 30-2.

20. Al-Khleif A, Damriyasa IM, Bauer C et al. A serosurvey for infections with Leptospira serovars in pigs from Bali, Indonesia. Deutsche Tierärztliche Wochenschrift 2009; 116(11): 389-91.

21. Jittapalapong S, Sittisan P, Sakpuaram T et al. Coinfection of Leptospira spp and Toxoplasma gondii among stray dogs in Bangkok, Thailand. The Southeast Asian journal of tropical medicine and public health 2009; 40(2): 247-52.

22. Boqvist S, Chau BL, Gunnarsson A et al. Animal- and herd-level risk factors for leptospiral seropositivity among sows in the Mekong delta, Vietnam. Preventive veterinary medicine 2002; 53(3): 233-45.

23. Benacer D, Zain SNM, Amran F et al. Isolation and Molecular Characterization of Leptospira interrogans and Leptospira borgpetersenii Isolates from the Urban Rat Populations of Kuala Lumpur, Malaysia. The American journal of tropical medicine and hygiene 2013; 88(4): 704-9.

24. Guernier V, Goarant C, Benschop J et al. A systematic review of human and animal leptospirosis in the Pacific Islands reveals pathogen and reservoir diversity. PLOS Neglected Tropical Diseases 2018; 12(5): e0006503.

25. Guernier V, Lagadec E, Cordonin C et al. Human Leptospirosis on Reunion Island, Indian Ocean: Are Rodents the (Only) Ones to Blame? PLoS Neglected Tropical Diseases 2016; 10(6): e0004733.

26. Hartskeerl RA, Smythe LD. The role of leptospirosis reference laboratories. Current topics in microbiology and immunology 2015; 387: 273-88.

27. Wynwood SJ, Burns MA, Graham GC et al. Serological diagnosis of Leptospirosis in bovine serum samples using a microsphere immunoassay. Veterinary Record Open 2016; 3(1): e000148.

28. Office International des Épizooties (OIE). Leptospirosis. 2014: 1-15. Available from: http:// www.oie.int/fileadmin/Home/eng/Health_standards/ tahm/2.01.09_LEPTO.pdf. Accessed 05 May 2018.

29. Ellis WA. Leptospirosis as a cause of reproductive failure. The Veterinary clinics of North America Food animal practice 1994; 10(3): 463-78.

30. Musso D, La Scola B. Laboratory diagnosis of leptospirosis: a challenge. Journal of microbiology, immunology, and infection = Wei mian yu gan ran za zhi 2013; 46(4): 245-52.

31. Brown C. Emerging Infectious Diseases of Animals: an Overview. Emerging Diseases of Animals: American Society of Microbiology 2000.

32. Levett PN. Leptospirosis. Clinical microbiology reviews. 2001; 14(2): 296-326.

Date of Submission: 2018-08-23 Date of Acceptance: 2018-08-31 